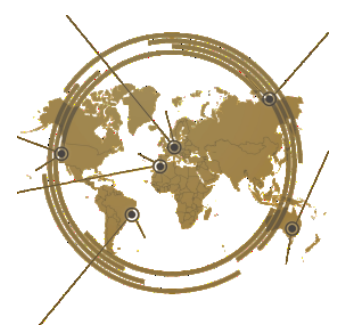

\title{
Pre-service teachers' beliefs about language teaching and learning in EFL classroom: A review of literature
}

\author{
Ririn Pusparini ${ }^{1 *}$, Utami Widiati ${ }^{2}$, Arik Susanti ${ }^{1}$ \\ ${ }^{1}$ English Department, Fakultas Bahasa dan Seni, Universitas Negeri Surabaya, ${ }^{2} E n g l i s h$ Department, Fakultas Sastra, \\ Universitas Negeri Malang
}

Pre-service teachers' (PST) beliefs and practices have been agreed as an initially vital basis to continue maintaining a qualified learning process. This article reviews the research on PSTs' beliefs and practices concerning teaching and learning English as a foreign language (EFL) and the exploration of the complex relationship between EFL PSTs' beliefs and practices. It encompasses a discussion about the nature of teachers' beliefs, an overview of PSTs' belief formation, and some previous studies on PSTs' beliefs. The review of related literature summarizes the empirical studies on PSTs' beliefs and practices from 2011 up to 2020, which reveal the diversity and similarity of the studies on EFL PSTs' beliefs. The result obtained in this study depicts that PSTs' beliefs about EFL teaching and learning are affected by prior language learning experiences, teacher education, and teaching practices. Besides, some constraints in the classroom setting can trigger the beliefs change covering time restriction, curriculum emphasis, students' misbehavior, students' competence, students' motivation, or even PSTs' motivation and confidence. Finally, when their tacit beliefs turn into explicit beliefs, PSTs can identify and assess their beliefs attributed to their classroom practices, from which EFL PST education can be informed to design better courses and prepare PSTs' future careers.

Keywords: pre-service teachers, beliefs, teaching, learning

OPEN ACCESS

ISSN 25033492 (online)

${ }^{*}$ Correspondence: Ririn Pusparini

ririnpusparini@unesa.ac.id

Received: 26th January 2021 Accepted: 24th April 2021 Published: 24th April 2021

Citation:

Pusparini, R. \& Widiati, U., and Susanti, A. (2021). Pre-service teachers' beliefs about language

teaching and learning in EFL classroom: A review of literature.

J. Eng. Educ. Society. 6:1. doi: $10.21070 /$ jees.v6i1.1212

\section{INTRODUCTION}

Belief is an essential topic in human behavior and learning. Some studies define teachers' beliefs as considerable ideas in understanding teachers' thought processes, teaching methods, and learning to teach (Borg, 2003; Xu, 2012; Löfström \& Poom-Valickis, 2013). They are important aspects in teacher education that have been designed to help teachers develop their thought and principles. More specifically, Löfström \& Poom-Valickis (2013) specifies teachers' beliefs as personal theories about teaching, influencing how teachers respond to certain situations, generating choices, and adopting particular strategies. Thus, beliefs are deemed as a key role in language teaching and learning.

Teacher beliefs, therefore, are significant in conducting teacher education designed to help PSTs develop their thinking and practices. In line with what Radwan (2019) states that comprehending the belief structures of future teachers is important to improving their professional preparation and teaching practices. While at the beginning of teacher education programs, they may have inappropriate and unrealistic understandings of teaching and learning (Borg, 2003). Henceforth, beliefs about language teaching and learning formatted by their previous knowledge will be influenced by the teacher education (Farrell \& Bennis, 2013). When they have teaching practicum, they are in a condition to transfer what they have learned from teacher education courses into the classroom, resulting in transforming 
theory into practices.

These beliefs, according to Richards and Theodore (2001), tend to shape their approaches to language teaching and inform and guide their teaching practices. In this regard, Jaimes (2013) conveys that when PSTs are in the classroom reality, they first seek to confirm and validate their teaching beliefs.Gradually, when they find proper conditions, they begin to use their growing knowledge to modify, adapt, and reconstruct their beliefs. Moreover, Seymen (2012) presents that the two elements might shape their beliefs and images. The first role is "teachers from the past who are seen as models," and the second one is "the students' self-image as learners."

In accordance with PSTs' beliefs, there are five types of PSTs' beliefs in the context of English for Foreign Language (EFL): beliefs about EFL learners and EFL learning, beliefs about EFL teaching, beliefs about EFL subject matter and pedagogical knowledge, beliefs about self, and beliefs about professional development (Fang, 2009). In this regard, it is undeniable that these different types of beliefs are interconnected. For instance, beliefs about teaching maybe closely related to beliefs about learning. If a PST believes language teaching should focus on CLT, this belief might be reflected on how the language taught and learned and what the teacher's role should be applied. Furthermore, Radwan (2019) explained that "Teaching is a very personal activity, and it is not surprising that individual teachers bring to teaching very different beliefs and assumptions about what constitutes effective teaching." In this regard, any incorrect beliefs about EFL teaching and learning can be detrimental to the students' learning and might negatively affect their future practices. For example, learners who believe in the importance of grammar are likely to spend considerable time focusing exclusively on memorizing grammar rules and paying less attention to other tasks. As these learners become teachers, they are likely to steer their future students into the same type of activities they were engaged during their training process. It is, hence, critical to helping these prospective teachers eliminate any detrimental beliefs before they start their careers as EFL teachers.

Nevertheless, a few PST studies focusing on describing the beliefs that these teachers hold on their teaching practicum at school have been conducted (Borg, 2015). Chaaban et al., (2019) confirms that most studies in accordance with teachers' beliefs were conducted on inservice teachers (novice teachers or experienced teachers) and their teaching practices. Moreover, studies of PSTs' research have been conducted for different purposes, e.g., tracking the changes in PSTs' beliefs of learning and teaching language components (Bangou et al., 2011; Debreli, 2012; MacAlister, 2012; Özmen, 2012; Altan, 2012; Capan, 2014; Saputra et al., 2020), identifying PSTs' beliefs of learning and teaching language skills (Gürsoy, 2013; Dinçer \& Yesilyurt, 2013; Tagle et al., 2017; Turnbull, 2017; Radwan, 2019), exploring PSTs' beliefs of language learning and teaching attributed to ELT methods and strategies (Seymen, 2012; Woodcock \& Reupert, 2013; Chan, 2014; Simsek, 2014; Kelly, 2018; Chaaban et al., 2019), and identifying PSTs' beliefs about language learning and teaching toward technology (Yerdelen-Damar et al., 2017; Nariyati et al., 2020; Hughes et al., 2020). These differences need to compile to disclose a clear picture of how PSTs' beliefs of language teaching and learning are reflected in EFL classroom teaching practices, why their beliefs change, how they change, and what constraints need to be aware. The findings will be essential to understand PSTs' beliefs about language teaching and learning and raise awareness about the importance of conducting research studies in TEFL education. Furthermore, students, teachers, teacher educators, and other stakeholders can also make use of the findings to establish a common vision of excellence in PST education.

On behalf of the need for the development of PST education and the importance of their beliefs in teacher education, the present review aims to examine themes related to EFL PST's' beliefs in English language teaching and learning and identify the role of their beliefs in EFL classroom. Thus, the present review was composed to address a research question, namely:

1. How are the current studies of pre-service teachers' beliefs about English language teaching and learning toward EFL classroom teaching practices?"

The next section of this review covers the methods in selecting the studies to develop the review and also present the key findings of the review, followed by section three, which discusses the results and discussion of the review, and finally, the conclusion based on the review findings is presented in the fourth section.

\section{METHODS}

This study is primarily based on the literature review on preservice teachers (PST)s' beliefs of English language teaching and learning in the EFL classroom. The peer-reviewed article is searched in the online databases of "Science Direct", "Scopus", "SINTA 1", and "SINTA 2". Specified key terms were selected, and expert/advanced search functions were utilized along with Boolean operators to come up with the following search string: ("pre-service teachers" OR "student teachers" OR "future teachers") AND ("beliefs" OR "perception") AND ("English language learning" OR "ELT" OR "English language teaching and learning) AND ("EFL classroom" OR "EFL context"). The key terms of awareness, impact, teacher training, practicum were included considering their close relation to PST's beliefs on English Language Teaching and Learning in EFL classroom. The search string was then inputted in the search field and searched for titles, abstracts and keywords. Furthermore, inclusion criteria were restricted to PSTs' beliefs research-based articles, published within the years of 2011 to 2020 time frame, in the context of English language teaching and learning and EFL, and related to the subjects of interest mentioned in the search string. As for the exclusion criteria, articles are deemed irrelevant with the subject of interest, non-English articles, publications before the year of 2011, and duplicate articles from the four web-based databases were eliminated carefully. 
With the key terms used in the search string mentioned above, a total of 1100 articles were found in Scopus, 411 articles in Science Direct, and 12 in SINTA 1 and 2 (Nov 20, 2020). Subsequently, with the inclusion criteria set to limit articles within EFL themes, the total articles were reduced to 35 articles in Scopus, 30 articles in Science Direct, and 5 articles in SINTA 1 and SINTA 2. Articles from other themes still showed up. After sifting thoroughly and eliminating irrelevant and duplicate articles from the four databases, a total of 22 articles taken from 15 articles in Scopus, 6 articles in Science Direct, and 1 article in SINTA 1 were finally selected. Then, the articles selected classified into 15 articles related to beliefs about EFL teaching and 7 articles related to beliefs about EFL learning. A summary of the search and selection process presented in Figure 1. Adapted from Boelens et al. (2017). $\mathrm{N}=$ Total number of selected articles.

The 22 articles were analyzed concerning: (a) the publication year, (b) measurement instruments, (c) the number of participants, and (d) the study result, and could be illustrated by Table 1 .

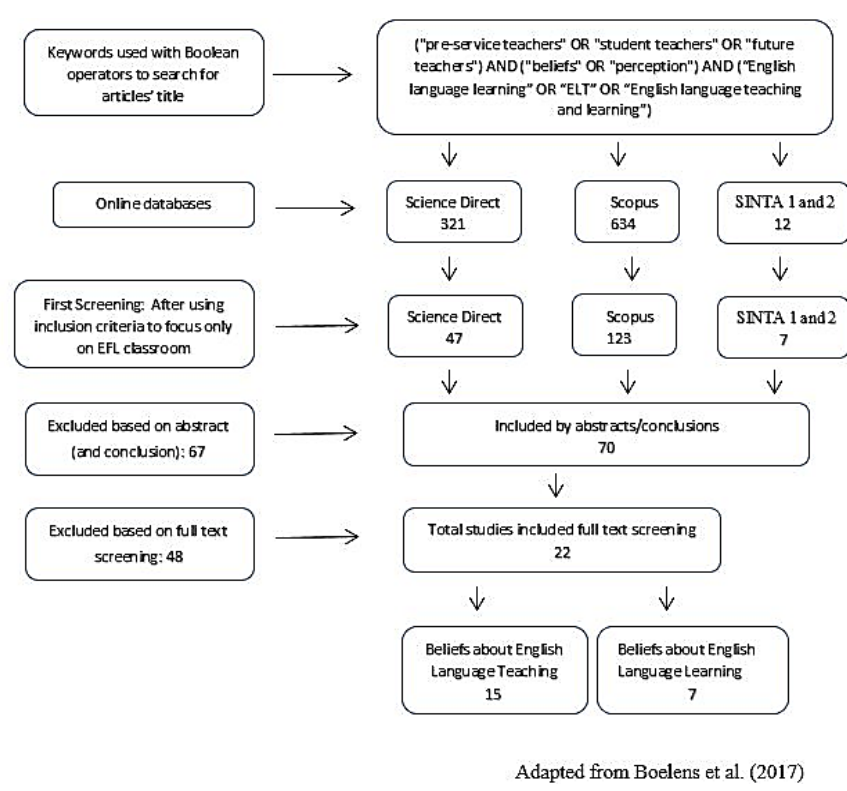

FIGURE $1 \mid$ Criteria and Procedure of Literature Search

Table 1. Previous research addressing PST beliefs about ELT and ELL

\begin{tabular}{|c|c|c|c|c|c|}
\hline Categories & Author & Year & Instrument & Participants & The Study Result \\
\hline \multirow[t]{5}{*}{$\begin{array}{l}\text { PSTs' beliefs } \\
\text { about English } \\
\text { Language } \\
\text { Teaching (ELT) }\end{array}$} & Emre Debreli & 2012 & Interview sheet & 3 & $\begin{array}{l}\text { PSTs' believed that group work in games, singing and pair- } \\
\text { work were regarded as distracting and difficult activities to } \\
\text { control. Besides, explicit correction sometimes proved to be } \\
\text { useful. }\end{array}$ \\
\hline & Esim Gursoy & 2013 & $\begin{array}{l}\text { Interviews and } \\
\text { observation sheets }\end{array}$ & 170 & $\begin{array}{l}\text { PSTs believe that teaching writing in English must be framed } \\
\text { within the process approach. }\end{array}$ \\
\hline & $\begin{array}{l}\text { Seyit Ahmet } \\
\text { Capan }\end{array}$ & 2014 & $\begin{array}{l}\text { Questionnaire, } \\
\text { interview, } \\
\text { observation sheets }\end{array}$ & 47 & $\begin{array}{l}\text { Most PSTs had strong beliefs about the importance of } \\
\text { presenting grammar through explicit instruction by using their } \\
\text { mother tongue to improve learners' consciousness about } \\
\text { grammatical rules. }\end{array}$ \\
\hline & $\begin{array}{l}\text { Sezen Seymen } \\
\text { Bilgin }\end{array}$ & 2016 & $\begin{array}{l}\text { Classroom } \\
\text { interaction } \\
\text { recording, individual } \\
\text { interviews and } \\
\text { stimulated recall } \\
\text { interviews }\end{array}$ & 5 & $\begin{array}{l}\text { PSTs viewed that they had to code switch most during grammar } \\
\text { instruction to provide explanation of grammatical items for the } \\
\text { students. }\end{array}$ \\
\hline & $\begin{array}{l}\text { Dwi Bayu } \\
\text { Spautra; Didi } \\
\text { Suherdi; Rojab } \\
\text { Siti Rodiyah } \\
\end{array}$ & 2020 & $\begin{array}{l}\text { Interviews and } \\
\text { classroom } \\
\text { observations }\end{array}$ & 3 & $\begin{array}{l}\text { PSTs viewed that lecturing the students or explaining a lesson } \\
\text { can create effective learning and grammar must be taught } \\
\text { exclusively in one meeting. More specifically, they believed } \\
\text { teachers as a transmitter of knowledge instead of a facilitator. }\end{array}$ \\
\hline \multirow[t]{4}{*}{$\begin{array}{l}\text { PSTs' beliefs } \\
\text { about English } \\
\text { Language } \\
\text { Learning (ELL) }\end{array}$} & $\begin{array}{l}\text { Kemal Sinan } \\
\text { Özmen }\end{array}$ & 2012 & Questionnaire & 49 & $\begin{array}{l}\text { PSTs believed that teacher should use written and oral context } \\
\text { and guide students to discover usage and language use. They } \\
\text { claimed that language learning as a process through which } \\
\text { individuals tried to develop their communicative competence. }\end{array}$ \\
\hline & $\begin{array}{l}\text { Tania Tagle, } \\
\text { Claudio Diaz, } \\
\text { Mark Ortiz, Lucia } \\
\text { Ubilla, Paulo } \\
\text { Etechegaray }\end{array}$ & 2017 & $\begin{array}{l}\text { Semi-structured } \\
\text { interview }\end{array}$ & 37 & $\begin{array}{l}\text { PSTs' beliefs were affected how they received the informatior } \\
\text { provided within the program. School background and teaches } \\
\text { education clearly influenced the development of the PSTs: } \\
\text { beliefs. }\end{array}$ \\
\hline & Adel Abu Radwan & 2019 & $\begin{array}{l}\text { Questionnaire, } \\
\text { observations, } \\
\text { interview }\end{array}$ & 212 & $\begin{array}{l}\text { PSTs believed in the importance of having opportunities to use } \\
\text { language, and fear of making mistakes might hinder speech } \\
\text { production and overcoming feelings of self-consciousness were } \\
\text { strong predictors of success in learning a language. }\end{array}$ \\
\hline & $\begin{array}{l}\text { Nariyati, } \\
\text { Sudirman, N. P. } \\
\text { A. Pratiwi }\end{array}$ & 2020 & $\begin{array}{l}\text { Questionnaire and } \\
\text { interview }\end{array}$ & 70 & $\begin{array}{l}\text { PSTs viewed that the integration of MALL was to facilitate } \\
\text { English learning in terms of time-efficient learning accessing } \\
\text { teaching-learning materials with unlimited time, and giving a } \\
\text { chance to be done anytime and anywhere. }\end{array}$ \\
\hline
\end{tabular}


Based on textual data analysis, I summarized PSTs' beliefs into two categories, namely (1) PSTs' beliefs about English language teaching and (2) PSTs' beliefs about English language learning.

\section{RESULTS AND DISCUSSION}

A total of 22 scholarly articles used to initiate answers addressing the proposed question about the current studies of PSTs' beliefs about English language teaching and learning and the role of their beliefs in EFL classroom. Below, I present the findings and discussion from the two categories by considering the results of the studies which are ELT or ELL as the focus of this article.

\section{PSTs' Beliefs in English Language Teaching}

Beliefs about teaching has restricted teachers' capability to open to new opinions (Borg, 2003). Teachers enter the teaching field with predetermined beliefs that can make better their classroom practices. Several studies investigated PSTs' beliefs about grammar instruction in EFL context (Debreli, 2012; Gürsoy, 2013; Capan, 2014; Saputra et al., 2020). Çapan (2014), for instance, investigated PSTs' beliefs about grammar instruction during their first teaching practices. The result of the study indicated that most of the participants agreed about the importance of grammar in EFL education. Prior to their practicum, they viewed grammar as "a tool rather than a goal" to help students express themselves. Besides, grammar should be taught implicitly by using a text rather than in isolation, subconsciously by embedding the role of using games or role-plays. Grammar is also essential in a communicative context or problem-solving activities.

CCapan (2014) conducted the research by distributing the questionnaires to 47 participants before and after the practices. However, he interviewed and observed 20 out of 47 participants' classroom teaching chosen based on their various beliefs. The result revealed that practically, 20 participants had strong beliefs about the importance of presenting grammar through explicit instruction by using their mother tongue to improve learners' consciousness about grammatical rules. Although they gave students opportunity to practice, they often interrupted. All of the constraints of PSTs' beliefs into teaching practices were due to time restriction and curriculum emphasis. It is in line with what Debreli (2012) found that PSTs' beliefs about the importance of implementing Communicative Language Teaching (CLT) in teaching grammar were changed during teaching practicum. Group work in games, singing, and pair-work were regarded as distracting and difficult activities to control.

Moreover, Gürsoy (2013) presented that PSTs viewed students should practice grammar rule via worksheet to learn it. This indicated that they considered worksheets as essential tools compared to games and role-plays. Likewise, Saputra et al. (2020) examined PSTs teaching beliefs and their teaching practices. The study was conducted by observing classroom interaction in Indonesian context and conducting depthinterviews for three participants. The result obtained indicated the changes between PSTs' beliefs about English learning and teaching and their practices. Prior to teaching practices, they believed that teachers should act as facilitators instead of only a knowledge transmitter, integrate grammar with other English aspects, involve students in a class, and lead them to find the grammar pattern through discussion and discovery learning. Practically, they perceived students primarily as the teaching objects rather than active and collaborative problem solvers of their learning in the classroom. They viewed that lecturing the students or explaining a lesson can create effective learning, and grammar must be taught exclusively in one meeting. More specifically, they believed teachers as a transmitter of knowledge instead of a facilitator. Eventually, all studies have a uniform idea that some constraints in teaching grammar make PSTs apply the traditional approach.

Seymen \& Bilqin (2016) conducted research by interviewing and observing five participants' classroom interaction. The result presented that PSTs viewed that they had to code switch most during grammar instruction to provide explanations of grammatical items for the students. The code switching was used to provide explanations and clarification. Another factor influencing code switching was PSTs' thought for they did not have sufficient competence as a native English speaker. This condition triggered them to apply code-switching. Meanwhile, Kandilla et al. (2011) found that when English was used as a means of instruction, the class was silent. Thus, PSTs believed that code-switching was one way to avoid students' misunderstanding related to the teacher's instruction and materials. On the other hand, Capan (2014) found PSTs believed that grammar rules should be explained in the first language (L1) and traditional way. They felt obliged to give grammar instructions in L1. Furthermore, in speaking and listening, the participants focused on the idea that practicing to communicate in the L2 must be done in English. However, what many failed to recognize was the indirect benefits of L1 use in the development of speaking and listening such as increasing learner's confidence, eliciting stress and anxiety, and offering a sense of security (Turnbull: 2017). The studies above have significant findings that PSTs view that English as the target language should not be used all along in a class mainly for explanation and clarification.

Several studies have examined PSTs' beliefs about vocabulary in EFL teaching and learning (MacAlister, 2012; Gürsoy, 2013; Andres et al., 2017; Turnbull, 2017). MacAlister (2012) investigated 60 Malaysian PSTs' beliefs about vocabulary teaching and learning by conducting interviews. The result obtained from this study revealed that reading was the best way to learn a new vocabulary since words were not learned in isolation. Moreover, Gürsoy (2013) indicated that pictures and objects could be utilized to learn new words. PSTs disagreed if vocabulary was learned by memorizing a word, but they favored vocabulary list with L1 translation. However, translation of a text for comprehension was rejected. Similarly, Turnbull (2017) stated that L1 could be used "sometimes" to aid FL reading, particularly in the translation of difficult vocabulary. Thus, findings from several studies above imply that PSTs argue that new vocabulary should be learned in context; meanwhile, translation is allowed only for the difficult words in reading comprehension.

Dinçer \& Yeșilyurt (2013) carried out a study about how PSTs were affected by their beliefs. The researcher studied PSTs' beliefs about speaking skills. The result of this study revealed that PSTs believed that gaining fluency in speaking took longer 
times and required a process, in which motivation played an essential role during the process. However, some of them remained to underestimate their speaking proficiency though they were excellent speakers. These negative thoughts about their competency might cease in succeeding their teaching practices. Meanwhile, Turnbull (2017) indicated that PSTs focused on the idea that practicing to communicate in the L2 must be done in English and subsequently disregarded any other roles of the L1. Hence, it was important to gain a native-like pronunciation as part of developing the speaking skill and know the foreign language's culture understudy to speak the language (Gürsoy, 2013; Altan, 2012). Thus, PSTs emphasize that they should have motivation and confidence, as well as knowing the culture to improve their speaking ability.

Tagle et al. (2017) used interviews to investigate teachers' beliefs about teaching writing and their effect on their learners' writing. The obtained results indicated that the teaching of writing in English should be delivered by way of different stages: planning, writing, revising and editing. This vision had been set up within the process approach instead of teaching students linguistic concepts. These teaching practices helped students organize their ideas, prepare, revise, and correct their written texts. Thus, these beliefs had a great impact on the teachers' classroom writing instruction. Moreover, Gürsoy (2013) presented that when developing the writing skill, PSTs believed that a word could not be considered as writing. However, writing should consist of at least a paragraph, and students made a draft in their first language. Two studies above reveal that PSTs believe that teaching writing in English must be framed within the process approach.

As for correcting errors, Debreli (2012) and Andres et al. (2017) investigated PSTs' beliefs on correcting students' errors. Debreli (2012) conducted interviews and classroom observation on three PSTs to gain more insights into the development of their beliefs. The obtained result indicated that participants believed that it was necessary to correct student errors implicitly. However, after their first teaching, they changed their beliefs and said that explicit correction sometimes proved to be useful. It is in line with Capan's (2014) findings that PSTs adopted a traditional approach which learners' errors were corrected by the teacher immediately. This traditional approach was deemed effective to provide learners with the opportunity to practice the target form. Meanwhile, Andres et al. (2017) carried out their study and found that PSTs believed that they must always correct students' mistakes, especially writing and speaking tasks. Thus, it is obvious that PSTs emphasize on a high priority to error correction in class.

Consequently, what PSTs believed that teaching could determine how they would teach in a classroom and what teaching methods and strategies would be adopted might affect learners' learning process and outcomes (Chan, 2014). Some studies had investigated teaching methods and strategies and learning to teach (Seymen, 2012; Simsek, 2014; Chan, 2014; Kelly, 2018; Chaaban et al., 2019). Kelly (2018) carried out a study by observing 12 PSTs' drawings during their teaching practices. The result revealed that their drawings illustrated their beliefs on direct instruction as an efficient and appropriate way to instruct students instead of cooperative learning that might result in confusion and wasted time. Besides, they also implemented enjoyable activities (i.e., drama and reading aloud) to engage students in the lesson. Similarly, Chan (2014) portrayed that PSTs believed in several ways of teaching: implementing many appropriate teaching methods, meeting students' needs, matching students' levels of English, and providing engaging activities for students. Additionally, Kandilla et al. (2011) found that PSTs believed in treating their students by giving different instruction based on students' characteristics. Meanwhile, students' motivation and eagerness to learn a language are essential aspects of teaching and could be regarded as the best learning method. In this case, PSTs emphasized that EFL teachers needed to control students' behavior and environment since students learned, practiced, and produced the language (Simsek, 2014) and employing rewards, initial corrections, and preventive strategies (Woodcock \& Reupert, 2013) were also necessary. Moreover, teachers' teaching motivation was also essential to consideras it determined the initiated teaching practices (Yüksel \& Kavanoz, 2015). The studies highlighted that PSTs believed in direct instruction based on students' characteristics and appropriate teaching methods to teach. They also believed in behavioral management, including motivation in language teaching and learning.

By conducting interviews with five participants, mid-and post- reflective essays, and weekly journals, Chaaban et al. (2019) investigated PSTs' views of their roles and whether their beliefs change during the practicum experiences. During the teaching practicum, the obtained result revealed that PSTs believed in their roles as provider, authority, participant, nurturer, interest arouser, technology specialist, and problem solver. However, one teacher role changed during the practicum since the teacher as facilitator turned into a teacher as an instructor in the sense that the teacher made the decisions during the lesson planning phase and then closely guided students through different activities. Meanwhile, Seymen (2012) found that PSTs' beliefs about their roles before the practicum were as facilitator, controller, and provider. During the practicum, they believed in the teacher as facilitator, activator, and organizer. However, Saputra et al. (2020) obtained the result that PSTs changed their beliefs about the teacher as a facilitator to a transmitter of knowledge in the practicum. Therefore, it is obvious that PSTs' roles during teaching practices are as provider, controller, participant, nurturer, interest arouser, technology specialist, and problem solver.

Teachers play an important role as decision-makers and designers of what and how they utilize technology in their classrooms. They also have to cope up all of the barriers and support for technology use in classrooms (Hutchison, 2012). Several studies investigated the PSTs' beliefs about the technology for conducting effective language teaching and learning (Yerdelen-Damar et al., 2017; Nariyati et al., 2020; Hughes et al., 2020). Yerdelen-Damar et al. (2017), for instance, identified how PSTs' beliefs about technological pedagogical content knowledge (TPACK) by interviewing 65 participants. The result found that if PSTs believed in their competence in TPACK, they would be more encouraged to integrate technology into their instruction effectively. Similarly, Hughes et al. (2020) found that 
PSTs believed in technology's ability for presenting materials, supporting visual needs, or engaging students. Therefore, PSTs positively view the benefits of technology in language teaching and learning. Their beliefs in their competence in TPACK motivate them to integrate technology into their teaching practices.

\section{PSTs' Beliefs about English Language Learning}

Teachers' views about how foreign language should be learned could interfere their way of teaching. One can visualize many ways in which teachers' beliefs about language learning may impact their teaching way in the classroom. For example, a PST who believes in grammar as an important component in learning a foreign language will spend most of his time to teach grammar. Henceforth, studies agreed that EFL PSTs should eliminate any detrimental beliefs which would likely influence their language teaching (Zheng, 2009).

The connection between PSTs' beliefs about language learning and their teaching practices have been presented by many research studies (Altan, 2012; Debreli, 2012; Özmen, 2012; Andres et al., 2017; Tagle et al., 2017; Radwan, 2019). Altan (2012), for instance, administered the questionnaire to 217 participants and examined PSTs' beliefs on language learning that could affect their instructional practices. The obtained result revealed that PSTs believed that learning a foreign language requires a special ability (language aptitude), and young age students have a better ability in language acquisition, especially pronunciation. These beliefs may discourage and demotivate adult language learners if this view was indirectly transmitted to students and the teaching practices might be negatively affected. In this regard, Debreli (2012) found that at the beginning of the training, PSTs believed that learning a foreign language needed a special ability; however, they all rejected that view after the classroom practices. This study revealed that PSTs emphasized that learning needed a process, and through that learning process, students would improve their foreign language.

Özmen (2012) administered the questionnaire and interviewed 47 PSTs to investigate the belief changes during the course education. The obtained result indicated that PSTs believed that language learning should start with learning grammar and vocabulary in the first year. However, at the end of the program, they changed their beliefs that teachers should use written and oral context and guide students to discover usage and language use. They claimed that language learning as a process through which individuals tried to develop their communicative competence. In this regard, teachers should be patient, resourceful, fun, and friendly. Similarly, Radwan (2019) also carried out a research to examine the changes in the PSTs' beliefs about EFL teaching and learning over the length training program. He conducted the research by administering questionnaire to 212 participants which had different study level. The result obtained revealed that students at the first study had strong beliefs about the importance of grammar and vocabulary in learning a foreign language and implied less emphasis on the communicative nature of learning a foreign language. They emphasized that it was better to postpone speaking activities after the students were sure that they could produce the language correctly. At the last level of education,

participants believed in the importance of having opportunities to use the language in language learning and the importance of cognitive and affective factors of success in learning a language. Their beliefs were based on the experience they got in schools that their target language was influenced by L1. They also viewed that fear of making mistakes might hinder speech production and overcoming feelings of self-consciousness were strong predictors of success in learning a language. In line with this study, Debreli (2012) stated that PSTs' beliefs were "contextually bounded and rooted" in their experiences within and outside the teacher education programs. Their beliefs were also affected how they received the information provided within the programs. School background and teacher education clearly influenced the development of the PSTs' beliefs (Gürsoy, 2013; Altan, 2012; Özmen, 2012; Tagle et al., 2017).

Regarding to technology, Nariyati et al. (2020) investigated EFL PSTs' beliefs about using Mobile Assisted Language Learning (MALL) in teaching EFL. By administering a questionnaire to 140 participants, the obtained results revealed that PST believed that the integration of MALL was beneficial for the learning process. In the learning process, the integration of MALL was believed to facilitate English learning in terms of time-efficient learning, accessing teaching-learning materials with unlimited time, and giving a chance to be done anytime and anywhere. Both teacher and students could implement MALL well in language teaching and learning since they used their mobile device for their daily activities.

Based on the above studies, it can be underlined that PSTs' beliefs about English language teaching and learning are affected by prior language learning experiences, teacher education, and teaching practices. Their prior experiences impact on what they learn and how they learn in their teaching programs. In this case, these prior experiences may have positive or negative impact on their beliefs. Teacher education program can help them eliminate any detrimental beliefs before they start their careers as EFL teachers, as some studies indicated the great impact of teacher education on changing PSTs' beliefs. Moreover, these beliefs also can be impacted by teaching practices since the beliefs might be changed due to some constraints covering: time restriction, curriculum emphasis, students' misbehavior, students' competence, students' motivation, or even PSTs' motivation and confidence. What teachers understand about particular changes in ELT is attributed to what they believe about it. Consequently, to have a deeper understanding of the specific changes in English language teaching; teachers must have a deeper understanding of their beliefs.

\section{CONCLUSION}

This study reviews some important issues related to PSTs' beliefs about language teaching and learning. Their beliefs are related to some factors that interact each other during teaching and learning processes. As it has been indicated in this review, EFL PSTs' beliefs are acquired from many years of learning experiences they got from schools to a teacher education, of which the condition has influenced what and how they learn to teach. 
These beliefs are the changes in teaching and learning process since one goal in teacher education should be oriented towards the formation of beliefs. Their beliefs, then, influence what they say and do in the classroom, which, in turn, shapes their beliefs. Besides, some constraints in the classroom setting can trigger the beliefs changed. Therefore, when their tacit beliefs turn into explicit beliefs, PSTs can identify and assess their beliefs attributed to their classroom practices, from which EFL PST education can be informed to design better courses and prepare PSTs' future careers.

\section{ACKNOWLEDGMENT}

This research was supported by Universitas Negeri Surabaya, Indonesia. The writers also would like to show their gratitude to the reviewer for the substantial feedback for the improvement of the manuscript.

\section{REFERENCES}

Altan, M. Z. (2012). Pre-service EFL teachers' beliefs about foreign language learning. European Journal of Teacher Education, 35(4), 481-493. https://doi.org/10.1080/02619768.2011.643399

Andres, S., Flórez, S., \& Basto, E. A. B. (2017). Identifying pre-service teachers' beliefs about teaching EFL and their potential changes. PROFILE, 19(2), 167-184. https://doi.org/10.15446/profile.v19n2.59675

Bangou, F., Fleming, D., \& Goff-Kfouri, C. A. (2011). Pre-service teachers' beliefs related to English as a second language and English as a foreign language: Where is the difference? Theory and Practice in Language Studies, 1(9), 10311040.https://doi.org/10.4304/tpls.1.9.1031-1040

Boelens, R., De Wever, B., \& Voet, M. (2017). Four key challenges to the design of blended learning: A systematic literature review. Educational Research Review, 22, 1-18. https://doi.org/10.1016/j.edurev.2017.06.001

Borg, S. (2003). Teacher cognition in language teaching: A review of research on what language teachers think, know, believe, and do. Language Teaching, 36(2), 81-109. https://doi.org/10.1017/S0261444803001903

Çapan, S. A. (2014). Pre-service English as a foreign language teachers' belief development about grammar instruction. Australian Journal of Teacher Education, 39(12), 131-152. https://doi.org/10.14221/ajte.2014v39n12.9

Chaaban, Y., Du, X., \& Ellili-Cherif, M. (2019). Influence of the practicum experience on student teachers' beliefs about their role in EFL classrooms. International Journal of Learning, Teaching and Educational Research, 18(9), 7895. https://doi.org/10.26803/ijlter.18.9.4
Chan, L. H. (2014). The change of conception of Englishlanguage teaching of Taiwanese EFL student-teachers after teaching practicum. Procedia - Social and Behavioral Sciences, 116, 194-198.

https://doi.org/10.1016/j.sbspro.2014.01.193

Debreli, E. (2012). Change in beliefs of pre-service teachers about teaching and learning English as a foreign language throughout an undergraduate pre-service teacher training program. Procedia - Social and Behavioral Sciences, 46(0044), 367-373.

https://doi.org/10.1016/j.sbspro.2012.05.124

Dinçer, A., \& Yeşilyurt, S. (2013). Pre-service English teachers' beliefs on speaking skill based on motivational orientations. English Language Teaching, 6(7), 88-95. https://doi.org/10.5539/elt.v6n7p88

Fang, Z. (2009). A review of research on teacher beliefs and practices. Educational Research, 38(1), 47-65. https://doi.org/10.1080/0013188960380104

Farrell, T. S. C., \& Bennis, K. (2013). Reflecting on ESL teacher beliefs and classroom practices: A case study. RELC Journal, 44(2), 163-176. https://doi.org/10.1177/0033688213488463

Gürsoy, E. (2013). What is effective in forming our beliefs: experience or education? Procedia - Social and Behavioral Sciences, 70, 763-770. https://doi.org/10.1016/j.sbspro.2013.01.121

Hughes, J. E., Cheah, Y. H., Shi, Y., \& Hsiao, K. H. (2020). Preservice and inservice teachers' pedagogical reasoning underlying their most-valued technology-supported instructional activities. Journal of Computer Assisted Learning, 36(4), 549-568. https://doi.org/10.1111/jcal.12425

Hutchison, A. (2012). Literacy teachers' perceptions of professional development that increases integration of technology into literacy instruction. Technology, Pedagogy and Education, 21(1), 37-56.

https://doi.org/10.1080/1475939X.2012.659894

Jaimes, J. C. (2013). The role of English pre-service teachers' beliefs about teaching in teacher education programs. Profile: Issues in Teachers' Professional Development, 15(1), 195-206.

Kandilla, D. P., Pebriyani, F., \& Meliana, S. S. (2011). Recalling student-teachers' beliefs on English language teaching: evidence from a pre-service. Journal of Teaching \& Learning English in Multicultural Contexts, 2(2).

Kelly, L. B. (2018). Preservice teachers' developing conceptions of teaching English learners. TESOL Quarterly, 52(1), 110-136. https://doi.org/10.1002/tesq.375

Löfström, E., \& Poom-Valickis, K. (2013). Beliefs about teaching: persistent or malleable? A longitudinal study of prospective student teachers' beliefs. Teaching and Teacher Education, 35, 104-113. https://doi.org/10.1016/j.tate.2013.06.004

MacAlister, J. (2012). Pre-service teacher cognition and vocabulary teaching. RELC Journal, 43(1), 99-111. https://doi.org/10.1177/0033688212439312

Nariyati, N. P. L., Sudirman, S., \& Pratiwi, N. P. A. (2020). EFL pre-service teachers' perception toward the use of mobile assisted language learning in teaching English. International Journal of Language Education, 4(2), 38. 
https://doi.org/10.26858/ijole.v4i2.10052

Özmen, K. S. (2012). Exploring student teachers' beliefs about language learning and teaching: A longitudinal study. Current Issues in Education, $15(1), 1-16$.

Radwan, A. (2019). Changes in prospective teachers' beliefs about foreign language learning in a teacher training program. Journal of Arts and Social Sciences, 10(2), 37-48.

Richards J.C and Theodore S. R. (2001). Approaches and Methods in Language Teaching. Cambridge (Cambridge University Press).

Saputra, D. B., Suherdi, D., \& Rodliyah, R. S. (2020). Reflective practice as tools to explore in-service teachers' beliefs and classroom practices: Indonesian EFL teachers' voices. JOALL (Journal of Applied Linguistics \& Literature), 5(2), 174-192. https://doi.org/10.33369/joall.v5i2.11260

Seymen, S. (2012). Beliefs and expectations of student teachers' about their self and role as teacher during teaching practice course. Procedia - Social and Behavioral Sciences, 46, 10421046.https://doi.org/10.1016/j.sbspro.2012.05.245

Seymen, S., \& Bilqin. (2016). Code switching in English language teaching ( ELT ) teaching practice in Turkey: Student teacher practices, beliefs and identity code switching in english language teaching ( ELT ) teaching practice in Turkey: Student teacher practices, beliefs and id. Academic Journals, 11(8), 686-702.

https://doi.org/10.5897/ERR2016.2802

Simsek, M. R. (2014). Examining preservice teachers' conceptions of language and the development of their teaching beliefs over the practicum. Procedia Social and Behavioral Sciences, 152, 937-942. https://doi.org/10.1016/j.sbspro.2014.09.346

Tagle, T., Díaz, C., Briesmaster, M., Ortiz, M., Ubilla, L., \& Etchegaray, P. (2017). Pre-service EFL teachers' beliefs about teaching writing: A case study in two Chilean Universities. Electronic Journal of Foreign Language Teaching, 14(2), 187-200.

Turnbull, B. (2018). Examining Pre-Service ESL Teacher Beliefs: Perspectives on First Language Use in the Second Language Classroom. Journal of Second Language Teaching \& Research, 6(2), 50-76.

Woodcock, S., \& Reupert, A. (2013). Does training matter? comparing the behaviour management strategies of pre-service teachers in a four-year program and those in a one-year program. Asia-Pacific Journal of Teacher Education, 4(1), 84-98. https://doi.org/10.1080/1359866X.2012.753991

$\mathrm{Xu}, \mathrm{L}$. (2012). The role of teachers' beliefs in the language teaching-learning process. Theory and Practice in Language Studies, 2(7), 1397-1402.

https://doi.org/10.4304/tpls.2.7.1397-1402
Yerdelen-Damar, S., Boz, Y., \& Aydın-Günbatar, S. (2017). Mediated effects of technology competencies and experiences on relations among attitudes towards technology use, technology ownership, and self-efficacy about technological pedagogical content knowledge. Journal of Science Education and Technology, 26(4), 394-405. https://doi.org/10.1007/s10956-017-9687-z

Yüksel, H. G., \& Kavanoz, S. (2015). Influence of prior experiences on pre-service language teachers' perception of teaching. Procedia - Social and Behavioral Sciences, 199, 777-784.

https://doi.org/10.1016/j.sbspro.2015.07.611

Zheng, H. (2009). A review of research on teacher beliefs and practices. Journal of Cambridge Studies, 4(1), 73-81. https://doi.org/10.1080/0013188960380104

Conflict of Interest Statement: The authors declare that the research was conducted in the absence of any commercial or financial relationships that could be construed as a potential conflict of interest.

Copyright ( 2021 Ririn Pusparini, Utami Widiati and Arik Susanti. This is an openaccess article distributed under the terms of the Creative Commons Attribution License (CC BY). The use, distribution or reproduction in other forums is permitted, provided the original author(s) and the copyright owner(s) are credited and that the original publication in this journal is cited, in accordance with accepted academic practice. No use, distribution or reproduction is permitted which does not comply with these terms. 